（6）Gaussian beam法を用いた伝播経路の影響による距離滅衰特性の考察

$\begin{array}{llllll}\text { 財団法人大阪土質試験所 } & \text { 香川 } & \text { 敬生 } & \text { 澤田 } & \text { 純男 岩崎 好規 } \\ \text { 関西電力株式会社 } & \text { 永野 } & \text { 徹 } & \text { 北野 剛人 大上 } & \text { 実 } \\ \text { 財団法人防災研究協会 } & \text { 吉川 } & \text { 宗治 } & & & \end{array}$

1.はじめに

一般に, 伝播経路特性は経験的な距離減衰特性を用いて評価されることが多いが, 伝播経路の構造, 物性值によ っては特徴的な影響を受けるものと考えられる。本研究では，異なる構造モデルによる伝播経路の影響を受けて地 表面波形が変化する様子および最大振幅の距離減衰性の変化を, Gaussian beam法を用いた数值計算例より考察する。 特に, 我が国の典型的な巨大地震であるサブダクション型の地震を内陸部で受ける場合の样に震央距離につれて上 部地款内の低速度層が厚くなるような場合に, 低速度層内の多重反射が伝播経路での距離減衰にどのような影響を 及ほすかを検討する。

\title{
2. 計算モデル・手法
}

Figure 1に示すように傾斜した低 速度層下面より地震波が入射する場 合, 震央距離が小さいと入射角も小 さくなり, 波動エネルギーの大部分 が低速度層内に入射するものの, 地 表面反射後の波動はその大部分が下 層に散逸するため, 直接波に比べて 低速度層内での反射波の振幅が著し く小さくなる。これに反して，震央 距離が大きくなるにつれて入射角は 大きくなり，低速度層に入射する波 動エネルギーは小さくなるものの, Short epicentral distance Long epicentral distance

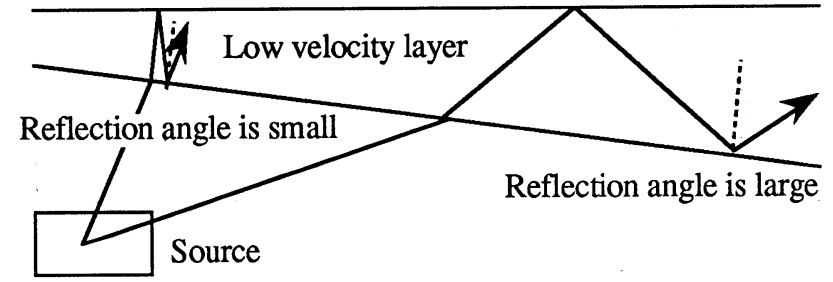

FIGURE 1 Effect of multiple reflections in low velocity layer. 地表面反射後に下層へ散逸するもの が少なくなり, 結果として直達波に比べて低速度層内の多重反射波が減衰しない傾向を示す。これに, より震央距 離の小さい地点で低速度層内に入射し, 多重反射を繰り返して伝播する波動が影響を及はし合い, 震央距離の大き い地点の波形は複雑に, かつ継続時間の長いものになると考えられる。このため, 震央距離の大きい地域での地表 面最大値振幅は直達波のみを想定した場合と は大きく異なることが考えられる。 TABLE 1 Physical characteristics of assumed model structure.

本研究では, これら低速度層内の多重反射 をGaussian Beam法[Cerveny et al.,1982, Benites and Aki, 1989 ]を用いて 2 次元 S H波動場に おいて計算し, 低速度層の傾斜が地表面最大 振幅の距離減衰性に及ほす影響を考察する。 計算に用いた構造モデルの物性値をTable 1に 示す。各層内の物性值は一定とし, ミラージ 層は考えない。また，震源でのラディエーシ ヨン特性は考慮していない。波形計算には低 速度層が水平, 震央距離とともに厚くなる, 薄くなるの 3 つのモデルを設定した。いずれのモデルも, Table 2に示すように低速度層のモデル内での平均層厚が 同じになるように設定している。Gaussian Beam法は初期值の設定などで注意深く計算を実施する必要がある[White et al., 1987]が, 複雑な形状のモデルでも簡便にかつ高速に計算することができ, 多重反射を考慮した伝播経路特性 を考察するには有効な手法であると考えられる。 
TABLE 2 Model cases with different inclination of boundaries between low velocity layer and lower layer

Case Boundary depth at $0 \mathrm{~km}$ Boundary depth at $300 \mathrm{~km}$ Dip angle Resulting figure

\begin{tabular}{lllll}
1 & $5.0 \mathrm{~km}$ & $5.0 \mathrm{~km}$ & 0.00 degrees & FIGURE 2 \\
2 & $3.0 \mathrm{~km}$ & $7.0 \mathrm{~km}$ & 0.76 degrees & FIGURE 3 \\
3 & $7.0 \mathrm{~km}$ & $3.0 \mathrm{~km}$ & -0.76 degrees & FIGURE 4 \\
\hline
\end{tabular}

\section{3. 計算結果・考察}

上記のモデルを用いて，震源にRicker's Waveletを与えて計算した波形をFigures 2 4に示す。低速度層が平行ある いは震央距離につれて薄くなる場合にはそれほど顕著ではないが, 低速度層が震央距離にともなって厚くなる場合 には震央距離につれ地表面波形が複雑化し, 直達波に比べて多重反射波の振幅が大きくなる傾向が認められる。ま たこの場合, 震央距離がある程度大きくなった地点より, 比較的振幅の大きい波群が低速度で伝播する様子が見ら れる。この波群は, 直達波とその周辺の波群が観測点の比較的近傍の多重反射波で構成されているのに対して, よ り震央距離の小さい部分より多重反射を繰り返して伝播する波動であると推定される。この計算結果は, 震央距離 の大きい地点では伝播経路での多重反射の影響を受けて地表面波形が複雑化し，そこでの波形から震源に関する情 報を抽出することは困難であること，またノイズレベルによっては多重反射波を初動と誤認する可能性があること を示唆するものである。

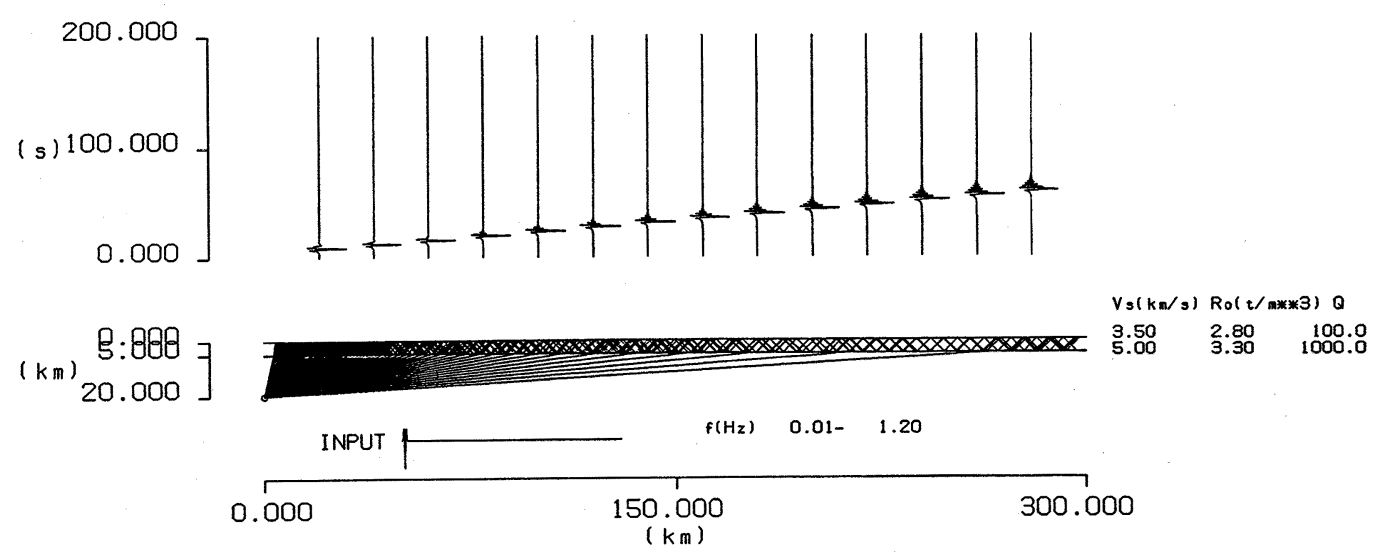

FIGURE 2 Result of Gaussian beam simulation with model structure of case 1 .

Figure 5には, 低速度層が震央距離につれて厚くなる場合について, 低速度層下面の傾きを変えて数值計算を実施 し, 各場合での最大振幅の距離減衰の様子を示す。図からは震央距離の小さい領域での最大振幅は震央距離のほほ 2 ３乗に反比例して小さくなっていることが読み取れる。半無限媒質を想定した直達波の距離隇衰は理論的には 距離の 1 乗に反比例するが, ここに示す計算では低速度層を想定しているため, この層への入射時にも震央距離と ともに振幅の減衰が生じるため, 半無限媒質の場合よりも大きな距離減衰特性を示しているものと考えられる。低 速度層下面が傾斜している場合には，ある震央距離を境にしてほほ震央距離に反比例する距離減衰を示すようにな り,このため震央距離の大きい地域での振幅が平行な低速度層の場合に比べて著しく大きくなる。これら距離減衰 


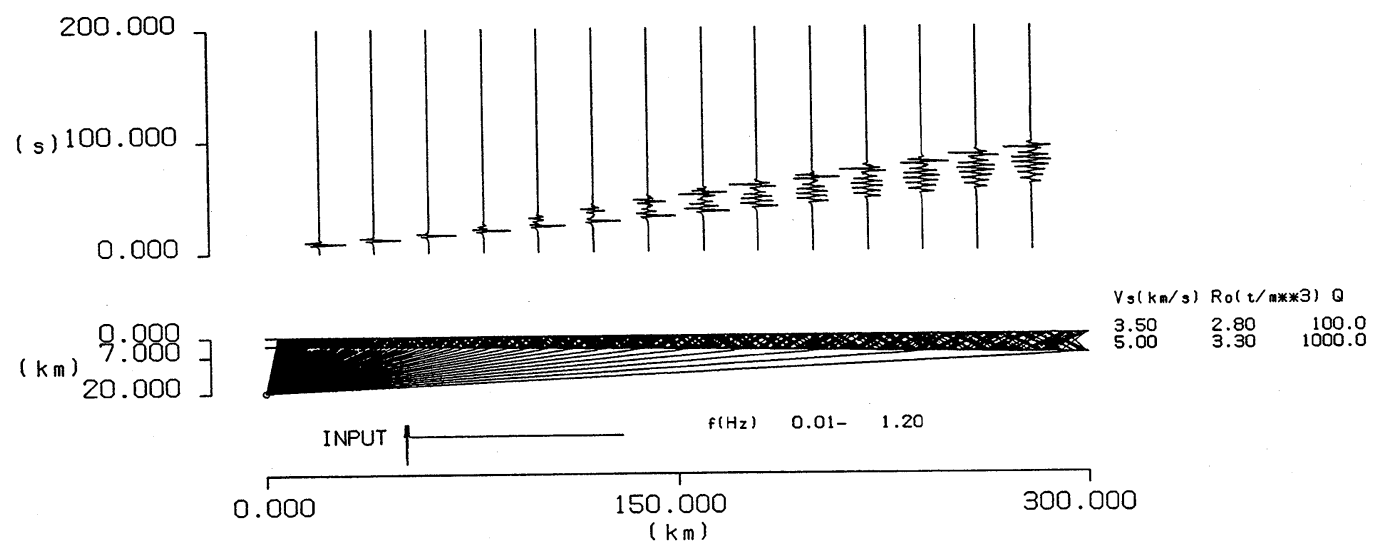

FIGURE 3 Result of Gaussian beam simulation with model structure of case 2.

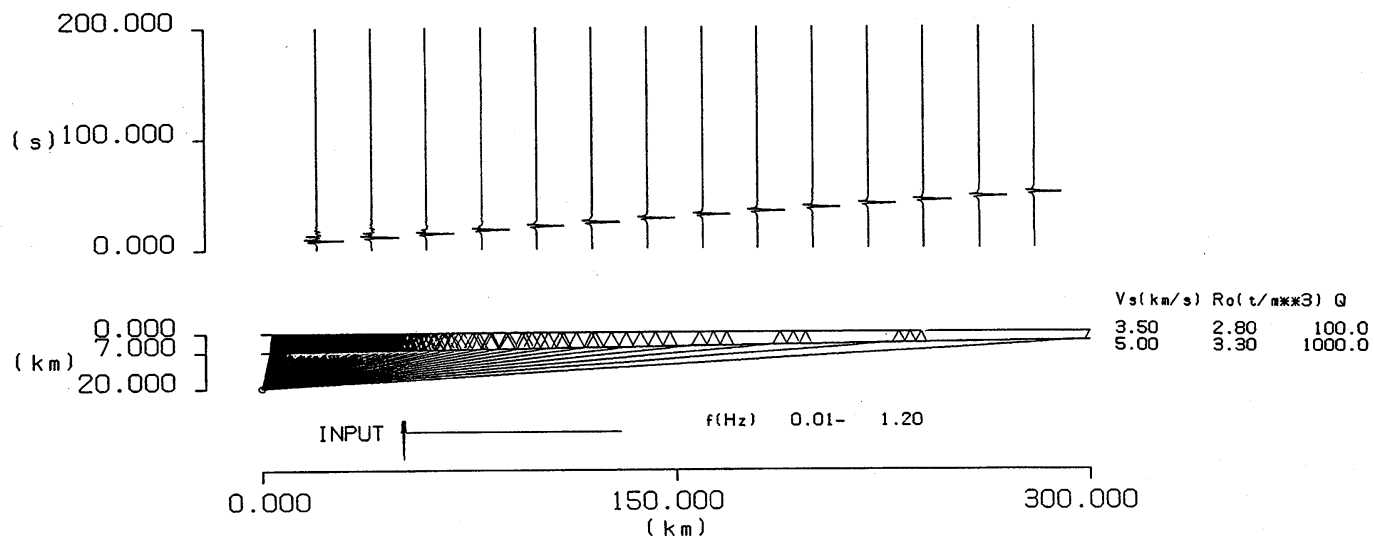

FIGURE 4 Result of Gaussian beam simulation with model structure of case 3.

性状が変化する震央距離は，Figure 4に示される波形で見ると多重反射波が卓越する距離に対応している。また，低 速度層下面の傾きが大きい程, 震央距離の小さい地点より距離隇衰が小さくなり, その結果として一定震央距離で の最大振幅は低速度層下面の傾きの大きい場合程大きくなる。このことは, 震央距離につれて厚くなる低速度層を 想定すると，ある震央距離までは従来の距離隇衰式よりもやや大きな距離隇衰を示すものの，それを越えると距離 減衰が著しく小さくなり, 場合によっては距離隇衰式で予想されるよりも大きな振幅を示す可能性が示唆される。 このように震央距離につれて低速度層が厚くなるケースは海洋性のサブダクション型の巨大地震を陸域で受ける場 合に相当し, 特にこの種の巨大地震が懸念される我が国では, 震央距離の大きい地域でも大きな震動を受ける可能 性があり，十分に検討しておくべき問題であると考えられる。また，サブダクションゾーンにおけるスラブの沈み 込みがP波直接波の走時と振幅に及ほす影響がWeber(1990)によって論じられており，本研究の成果と併せて興味深 w。 


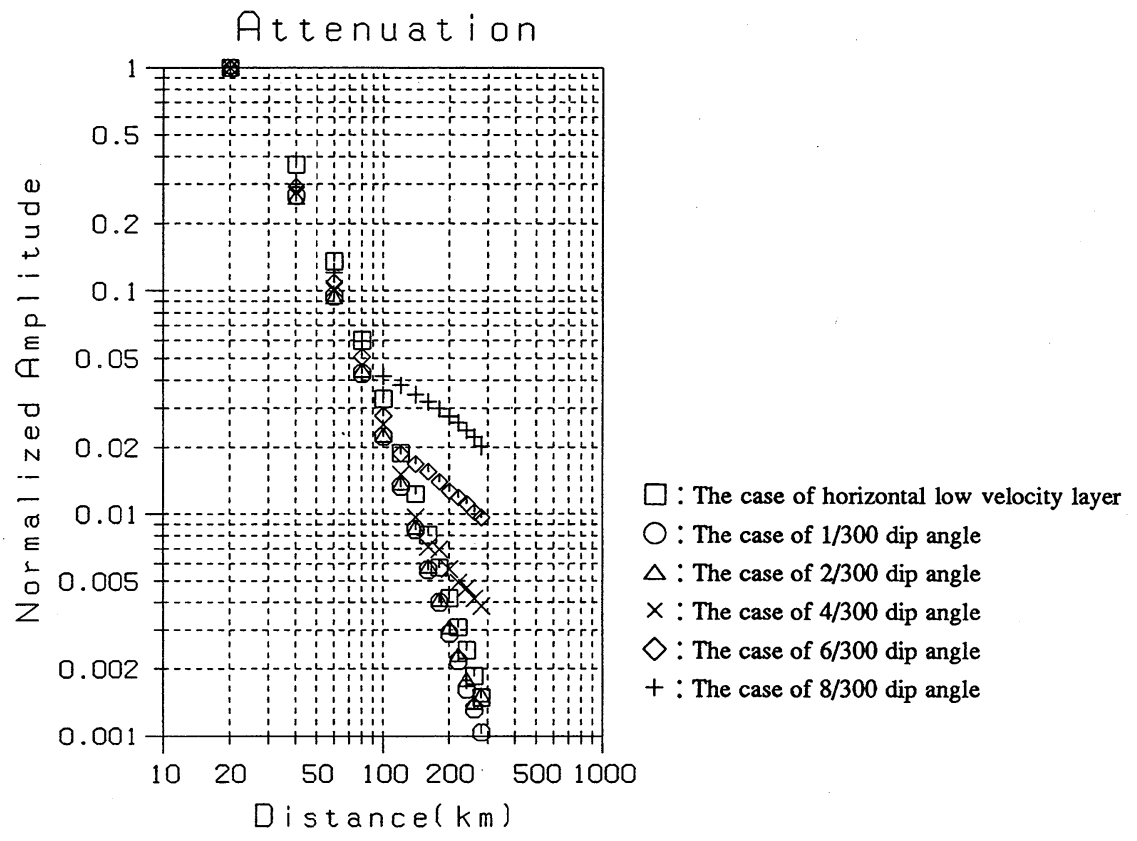

FIGURE 5 Change of attenuations due to the difference of dip angle of the boundary between upper low velocity crustal layer and lower crustal layer.

4.おわりに

傾斜構造等，複雑な構造を伝播する波動の距離減衰特性を，Gaussian beam法を用いた数值計算例より考察をおこ なった。その結果, 震央距離につれて厚くなるような低速度層が存在する場合, 低速度層内の多重反射の影響を受 けて距離減衰性が著しく減少し，震央距離の大きい領域での振幅が一般の距離減衰式で予想されるよりも大きくな る可能性が示された。このようなケースはサブダクション型の地震動を内陸地域で受ける場合に相当し，サブダク ション型の大地震による被害が懸念される我が国では重要な問題となろう。また同計算より, 震央距離につれて地 震波形が複雑化し，震動継続時間が長くなる現象の要因のひとつが低速度層内の多重反射に起因するものである可 能性が示唆された。今後, 観測記録を用いたアプローチを実施してゆきたい。

\section{謝 辞}

この研究を進めるにあたり，京都大学防災研究所入倉孝次郎教授には終始貴重なアドバイスを頂きました。また， 京都大学防災研究所地震動部門の松井一郎氏には, Gaussian Beam法に関して大变有意義な議論をして頂きました。 ここに記して感謝致します。

\section{参考文献}

1. R.Benites and K. Aki, "Boundary Integral-Gaussian Beam Method for Seismic Wave Shattering : SH Wave in Twodimensional Media", J.Acoust.Soc.Am. 86(1) : 375-386(July 1989).

2. V.Cerveny, M.M.Popov, and I.Psencik, "Computation of Wave Field in Inhomogeneous Media - Gaussian Beam Approach-", Geophys.J.R.astr.Soc. 70 : 109-128(1982).

3. M.Weber, "Subduction Zones-Their Influence on Traveltime and Amplitudes of P-waves", Geophys.J.Int. 101 : $529-544$ (1990).

4. B.S.White, A.Norris, A.Bayliss and R.Burridge, "Some Remarks on the Gaussian Beam Summation Method", Geophys.J.R. astr.Soc. $89:$ 579-636(1987). 